\title{
MEKANISME PEMUNGUTAN PAJAK ATAS PEMINDAHAN HAK PADA JUAL BELI TANAH DAN BANGUNAN DI KABUPATEN KEPULAUAN SIAU TAGULANDANG BIARO (SITARO)
}

\author{
Sela Pudihang ${ }^{1}$, Jenny Morasa ${ }^{2}$, Hendrik Gamaliel $^{3}$ \\ ${ }^{12}{ }^{3}$ Fakultas Ekonomi dan Bisnis. Jurusan Akuntansi. Universitas Sam Ratulangi, Jl. Kampus Bahu, Manado, \\ 95115, Indonesia. \\ E-mail :selapudihang@gmail.com
}

\begin{abstract}
The BEA acquisition of Rights over the land and building tax is imposed on the acquisition of land rights and buildings. The tax was enacted by the Central Government into tax areas since January 2011. Islands Regency Siau In Indonesia this tax set forth in applicable local Islands Regency Siau In Indonesia number 5 in 2011 about tax areas. The purpose of the study to analyze the tax collection mechanism BPHTB Islands Regency Siau In Indonesia. Methods of analysis used qualitative descriptive. Data collection is done by the method of interview, observation and documentation. The research results of the tax collection mechanism BPHTB through stage charging SSPD BPHTB, stage counting BPHTB payable, the payment stage, verification has not been effective. To improve the understanding of the taxpayers of the County Financial Agency then BPHTB Siau In Indonesia more being proactive by increasing the activities of socialization, because of taxpayer compliance in reporting the Bea acquisition of Rights over the land and buildings in the Regency Siau In Indonesia is still lacking.
\end{abstract}

Keywords: tax collection Mechanisms, BPHTB, buying and selling land and buildings

\section{PENDAHULUAN}

\subsection{Latar Belakang}

Indonesia sebagai negara berkembang sedang melakukan berbagai pembangunan disegala bidang menuju masyarakat yang adil dan makmur. Pajak merupakan salah satu sumber penerimaan negara yang sangat penting bagi penyelenggaraan pemerintah dan pelaksanaan pembangunan nasional. Secara umum jenis-jenis pajak yang dipungut diantaranya, yaitu: Pajak Penghasilan (PPh), Pajak Pertambahan Nilai (PPN), Pajak Bumi dan Bangunan (PBB), dan Pajak Bea Perolehan Hak Atas Tanah dan Bangunan (BPHTB).

Jenis-jenis pajak tersebut terbagi atas pajak pusat dan pajak daerah. Pajak pusat adalah PPh dan PPN. Sementara itu, pajak daerah adalah PBB dan BPHTB. Kedua jenis pajak daerah terkait menjadi andalan pemerintah daerah untuk menambah pendapatan dalam menyelenggarakan program pemerintah guna meningkatkan kegiatan pembangunan, menyebabkan meningkatnya keperluan akan tersedianya tanah dan atau bangunan.

Sedangkan tanah dan atau bangunan persediaannya sangat terbatas. Mengingat pentingnya tanah dan atau bangunan tersebut dalam kehidupan, maka sudah sewajarnya jika orang pribadi atau badan hukum yang mendapatkan nilai ekonomis serta manfaat dari tanah dan atau bangunan karena adanya perolehan hak atas tanah dan atau bangunan dikenakan pajak oleh negara. Pajak tersebut diatur dalam Undang-Undang RI Nomor 20 Tahun 2000 tentang Bea Perolehan Hak atas Tanah dan Bangunan. 
Sehubungan dengan berlakunya Undang-Undang Nomor 28 Tahun 2009 tentang Pajak Daerah dan Retribusi Daerah. Wewenang untuk memungut BPHTB diserahkan ke pemerintah kabupaten/kota. Penyerahan pengelolaan BPHTB kepada pemerintah kabupaten/kota mulai efektif berlaku sejak 1 Januari 2011. Pengalihan BPHTB dari pajak pusat menjadi pajak daerah merupakan langkah strategis dalam pelaksanaan desentralisasi fiskal di Indonesia (Soewardi,2014).

Suatu pemungutan pajak pada umumnya, pasti ada aturan yang menjadi dasar pengenaannya. Pemerintah Daerah Kabupaten Kepulauan SITARO mengatur mengenai BPHTB dalam Peraturan Daerah Kabupaten Kepulauan Siau Tagulandang Biaro Nomor 5 Tahun 2011 tentang Pajak Daerah, pada Bab II Bagian Kedelapan.

Dalam pelaksanaan pemungutan BPHTB salah satunya yaitu pemindahan hak atas jual beli tanah dan bangunan merupakan suatu aktivitas yang dilakukan oleh masyarakat yang dapat memberikan pemasukan berupa pajak dalam jumlah yang besar bagi negara dalam hal ini pemungutannya dilakukan oleh pemerintah daerah. Jual beli merupakan suatu perbuatan hukum yang dapat menimbulkan hutang pajak. Terdapat beberapa pihak yang terkait dalam pelaksanaan pemungutannya, seperti masyarakat atau wajib pajak, Pejabat Pembuat Akta Tanah (PPAT) atau Camat selaku pejabat sementara yang berwenang untuk membuat akta peralihan hak tanah, dan bidang pendapatan selaku instansi yang berwenang untuk melakukan pemungutan pajak. Peran PPAT/Camat dalam transaksi jual beli tanah merupakan suatu bagian penting karena wajib pajak lebih mengetahui adanya pengenaan BPHTB atas pemindahan hak atas tanah dan bangunan ini dari pihak PPAT/Camat.

Berdasarkan pemaparan singkat latar belakang masalah di atas, penulis tertarik untuk meneliti tentang “ Mekanisme Pemungutan Pajak atas Pemindahan Hak pada Jual Beli Tanah dan Bangunan Di Kabupaten Kepulauan Siau Tagulandang Biaro (SITARO) ”.

\subsection{Tujuan Penelitian}

Adapun tujuan yang ingin dicapai dalam penelitian ini Untuk menganalisis bagaimana mekanisme pemungutan Pajak BPHTB yang ada di Kabupaten Kepulauan SITARO.

\section{TINJAUAN PUSTAKA}

\subsection{Konsep Akuntansi Pajak}

Menurut Supriyanto (2011: 2-3) Akuntansi Pajak adalah suatu proses pencatatan, penggolongan, dan pengikhtisaran suatu transaksi keuangan kaitannya dengan kewajiban perpajakan dan diakhiri dengan pembuatan laporan keuangan fiskal sesuai dengan ketentuan dan peraturan perpajakan yang terkait sebagai dasar pembuatan surat pemberitahuan tahunan.

\subsection{Konsep Perpajakan \\ Definisi Pajak}

Definisi pajak menurut Undang-Undang Nomor 16 tahun 2009 tentang Ketentuan Umum dan Tata Cara perpajakan pada pasal 1 ayat 1 berbunyi "Pajak adalah kontribusi wajib kepada negara yang terutang oleh orang pribadi atau badan yang bersifat memaksa berdasarkan Undang-Undang, dengan tidak mendapatkan imbalan secara langsung dan digunakan untuk keperluan negara bagi sebesar-besarnya kemakmuran rakyat".

\section{Fungsi Pajak}

Menurut Hidayat (2011: 6) pajak mempunyai beberapa fungsi, yaitu:

1. Fungsi Anggaran (Budgeter) 
2. Fungsi Mengatur (Regulerend)

3. Fungsi Stabilitas

4. Fungsi Retribusi Pendapatan

\section{Pengelompokan Pajak}

Menurut Mardiasmo (2016: 6) pajak dikelompokan sebagai berikut:

1. Menurut Golongannya
a. Pajak Langsung
b. Pajak Tidak Langsung

2. Menurut Sifatnya
a. Pajak Subjektif
b. Pajak Objektif

3. Menurut Lembaga Pemungutnya
a. Pajak Pusat
b. Pajak Daerah

\section{Tata Cara Pemungutan Pajak}

1. Stelsel Pajak

Pemungutan pajak dapat dilakukan berdasarkan 3 stesel:
a. Stelsel Nyata (riel stelsel)
b. Stelsel Anggapan (fictieve stelsel)
c. Stelsel Campuran

2. Asas Pemungutan Pajak
a. Asas Domisili (asas tempat tinggal)
b. Asas Sumber
c. Asas Kebangsaan

3. Sistem Pemungutan Pajak

Sistem pemungutan pajak dapat dikelompokan menjadi 3 jenis (Mardiasmo, 2016: 9):
a. Official Assessment System
b. Self Assessment System
c. Withholding System

\section{Syarat Pemungutan Pajak}

Agar pemungutan pajak tidak menimbulkan hambatan atau perlawanan, maka pemungutan pajak harus memenuhi syarat sebagai berikut, Mardiasmo (2016: 5)

1. Pemungutan pajak harus adil (syarat keadilan)

2. Pemungutan pajak harus berdasarkan undang-undang (syarat yuridis)

3. Tidak menganggu perekonomian (syarat ekonomis)

4. Pemungutan pajak harus efisien (syarat finansiil)

5. Sistem pemungutan pajak harus sederhana.

\section{Prinsip Pemungutan Pajak}

Menurut Era Saligman yang dikutip oleh (Rooy 2016) ada empat jenis prinsip pemungutan pajak, yaitu sebagai berikut:

1. Prinsip Fiskal

2. Prinsip Ekonomi

3. Prinsip Etika 


\section{Prinsip Administratif}

\subsection{Pajak Daerah}

Dasar Hukum pemungutan Pajak Daerah dan Retribusi Daerah adalah Undangundang No. 28 Tahun 2009 tentang Pajak Daerah dan Retribusi Daerah. Pengertian Pajak Daerah, yang selanjutnya disebut pajak, adalah kontribusi wajib kepada Daerah yang terutang oleh orang pribadi atau badan yang bersifat memaksa berdasarkan Undang-Undang, dengan tidak mendapatkan imbalan secara langsung dan digunakan untuk keperluan Daerah bagi sebesar-besarnya kemakmuran rakyat.

\subsection{Konsep BPHTB \\ Filosofi BPHTB}

Filosofi utama yang melandasi adanya pajak karena peran serta masyarakat pembangunan dan meningkatkan kesejahteraan serta kemakmuran rakyat melalui peningkatan penerimaan Negara dengan cara pengenaan pajak. Bea Perolehan atas Tanah dan Bangunan termasuk pengenaan pajak.

ada beberapa ciri khusus yang membuat BPHTB dinamai bea bukan pajak, karena:

1. Bea materai tidak diperlukan nomor identitas baik untuk wajib pajak maupun objek pajak

2. Saat pembayaran pajak terjadi lebih dahulu daripada saat terutang

3. Frekuensi pembayaran bea terutang dapat dilakukan secara insidentil dan tidak terikat dengan waktu. Misalnya, ketika membeli (membayar) materai tempel dapat dilakukan kapan saja, demikian pula membayar BPHTB terutang. Hal ini berbeda dengan pengenaan pajak harus dibayar sesuai dengan waktu yang sudah ditentukan. (Windy, 2016)

\section{Pengertian BPHTB}

Bea Perolehan Hak atas Tanah dan Bangunan (BPHTB) adalah pajak yang dikenakan atas perolehan hak atas tanah dan/atau bangunan. Dalam hal ini BPHTB selanjutnya disebut pajak, sedangkan Perolehan hak atas tanah dan/atau bangunan, adalah perbuatan atau peristiwa hukum yang mengakibatkan diperolehnya hak atas tanah dan/atau bangunan oleh orang pribadi atau badan. Hak atas tanah dan atau bangunan, adalah hak atas tanah, termasuk hak pengelolaan, beserta bangunan di atasnya, sebagaimana dimaksud dalam Undang-undang Nomor 5 Tahun 1960 tentang Peraturan Dasar Pokok-pokok Agraria, UU No 16 Tahun 1985 tentang Rumah Susun, dan ketentuan peraturan Perundang-undangan yang berlaku lainnya.

\section{Dasar Hukum BPHTB}

1. Undang-Undang Republik Indonesia Nomor 28 Tahun 2009 tentang Pajak Daerah dan Retribusi Daerah

2. Undang-undang Nomor 20 Tahun 2000 tentang Bea Perolehan Hak Atas Tanah dan Bangunan.

3. Peraturan Daerah Kabupaten Kepulauan Siau Tagulandang Biaro Nomor 5 Tahun 2011 tentang Pajak Daerah. Pada Bab II Bagian Kedepalan.

\section{Subjek dan Wajib Pajak BPHTB}

Subjek Pajak BPHTB adalah orang pribadi atau Badan yang memperoleh Hak atas Tanah dan/atau Bangunan. 


\section{Objek Pajak BPHTB}

Objek BPHTB adalah perolehan hak atas tanah dan/atau bangunan. Perolehan hak atas tanah dan/atau bangunan meliputi :

1. Pemindahan hak karena :

Jual-beli, Tukar-menukar, Hibah, Hibah wasiat, Waris, Pemasukan dalam perseroan atau badan hukum lainnya, Pemisahan hak yang mengakibatkan peralihan, Penunjukan pembeli dalam lelang, Pelaksanaan putusan hakim yang mempunyai kekuatan hukum tetap, Penggabungan usaha, Peleburan usaha, Pemekaran usaha, Hadiah.

2. Pemberian hak baru karena :

Kelanjutan pelepasan hak dan Di luar pelepasan hak.

\section{Tidak Termasuk Objek Pajak BPHTB}

Objek pajak yang tidak dikenakan BPHTB adalah objek pajak yang diperoleh (Resmi, 2012: 260) :

1. Perwakilan diplomatik, konsulat berdasarkan asas perlakuan timbal balik

2. Negara untuk penyelenggaraan pemerintahan dan/atau pelaksanaan pembangunan guna kepentingan umum

3. Badan atau perwakilan organisasi internasional yang ditetapkan dengan Keputusan Menteri dengan syarat tidak menjalankan usaha atau melakukan kegiatan lain di luar fungsi dan tugas badan usaha atau perwakilan organisasi tersebut

4. Orang pribadi atau badan karena konversi hak atau karena perbuatan hukum lain dengan tidak adanya perubahan nama.

5. Orang pribadi atau badan karena wakaf.

6. Orang pribadi atau badan yang digunakan untuk kepentingan ibadah.

7. Objek pajak tertentu.

\section{Dasar Pengenaan BPHTB}

Dasar pengenaan pajak adalah Nilai Perolehan Objek Pajak (NPOP) yang ditentukan dalam Peraturan Daerah Kabupaten Kepulauan SITARO Nomor 5 Tahun 2011 :
a. Jaul beli adalah harga transaksi
b. Tukar-menukar adalah nilai pasar
c. Hibah adalah nilai pasar
d. Hibah wasiat adalah nilai pasar
e. Waris adalah nilai pasar
f. Pemasukan dalam perseroan atau badan hukum lainnya adalah nilai pasar
g. Pemisahan hak yang mengakibatkan peralihan hak adalah nilai pasar
h. Peralihan hak karena pelaksanaan putusan hakim yang mempunyai kekuatan hukum tetap adalah nilai pasar
i. Pemberian hak baru atas tanah sebagai kelanjutan dari pelepasan hak adalah nilai pasar
j. Pemberian hak baru atas tanah di luar pelepasan hak adalah nilai pasar
k. Penggabungan usaha adalah nilai pasar
1. Peleburan usaha adalah nilai pasar
m. Pemekaran usaha adalah nilai pasar
n. Hadiah adalah nilai pasar dan/atau
o. penunjukan pembeli dalam lelang adalah harga transaksi yang tercantum dalam risalah lelang.




\section{Nilai Perolehan Objek Pajak Tidak Kena Pajak}

Nilai Perolehan Objek Pajak Tidak kena Pajak (NPOPTKP) dalam Peraturan Daerah Kabupaten Kepulauan Siau Tagulandang Biaro Nomor 5 Tahun 2011 di tetapkan:

a. Rp. 60.000 .000 (enam puluh juta rupiah) untuk setiap wajib pajak

b. Rp. 300.000.000 (tiga ratus juta rupiah) dalam hal perolehan hak karena waris atau hibah wasiat yang diterima orang pribadi yang masih dalam hubungan keluarga sedarah dalam garis keturunan lurus satu derajat keatas atau satu derajat kebawah dengan pemberi hibah wasiat, termasuk suami/istri.

\section{Tarif Pajak}

5\% x Nilai Perolehan Objek Pajak Tidak kena Pajak (NPOPTKP).

\subsection{Penelitian Terdahulu}

1. Merda Arianti (2014) dengan judul Mekanisme Pemungutan Pajak Bea Perolehan Hak atas Tanah dan Bangunan (BPHTB) Pada Kantor Dinas Pengelolaan Keuangan dan Aset Kabupaten Rokan Hulu. Tujuan penelitian mengetahui pelaksanaan pemungutan dan mengetahui faktor-faktor apa saja yang menjadi penghambat dalam pemungutan Bea Perolehan Hak atas Tanah dan Bangunan di Dinas Pengelolaan Keuangan dan Aset Kabupaten Rokan Hulu. Metode yang digunakan analisis kualitatif. Hasil penelitian menunjukan bahwa Mekanisme pemungutan pajak BPHTB terdiri dari tujuh tahap yaitu pengurusan Akta Pemindahan Hak atas Tanah dan/atau Bangunan, pembayaran BPHTB, Penelitian Surat Setoran Pajak Daerah (SSPD BPHTB), pendaftaran Akta Pemindahan Hak atas Tanah dan/atau Bangunan, pelaporan BPHTB, penagihan pajak BPHTB dan pengurangan BPHTB yang dilakukan Dinas Pengelolaan Keuangan dan Aset Kabupaten Rokan Hulu.

2. Elga Anggraini (2015) dengan judul Analisis Penerapan Pemungutan Bea Perolehan Hak atas Tanah dan Bangunan (BPHTB) di Kabupaten Malang. Tujuan penelitian mengetahui potensi BPHTB, prosedur BPHTB, faktor-faktor pendukung dan penghambat, dan efektivitas pemungutan BPHTB di Kabupaten Malang. Metode yang digunakan deskriptif. Hasil penelitian menunjukan bahwa hasil dari pemungutan BPHTB untuk PAD Kabupaten Malang cukup tinggi dan dalam pelaksanaannya menunjukkan hasil sangat efektif karena realisasi di atas $100 \%$ dari target yang ditetapkan.

3. Andi Cahyono (2014) dengan judul Analisa Pemungutan Bea Perolehan Hak atas Tanah dan Bangunan (BPHTB) Dalam Hal Jual Beli Tanah dan Bangunan Di Kota Blitar. Tujuan penelitian menganalisa pemungutan BPHTB di Kota Blitar. Metode yang digunakan kualitatif. Hasil penelitian menunjukan bahwa Realisasi pendapatan daerah dari sektor BPHTB melebihi target yang ditetapkan dan BPHTB dari sektor jual beli memberikan kontribusi pendapatan terbanyak, namun dalam hal pemungutan BPHTB proses penelitian SSPD BPHTB masih kurang sesuai dengan peraturan walikota Blitar Nomor 9 Tahun 2011.

\section{PENELITIAN}

\subsection{Jenis Penelitian}

Jenis penelitian ini adalah penelitian deskriptif kualitatif. Penelitian deskriptif kualitatif meliputi pengumpulan data untuk diuji atau menjawab pertanyaan mengenai status terakhir dari subjek penelitian (Kuncoro, 2013: 12). Deskriptif kualitatif yaitu penelitian yang dilakukan untuk mengetahui nilai variabel mandiri, baik satu variabel atau lebih dan tidak 
terdapat perbandingan atau menghubungkan dengan variabel lain, yang datanya dinyatakan dalam bentuk verbal dan dianalisis tanpa menggunakan teknik statistik.

\subsection{Tempat dan Waktu Penelitian}

Tempat penelitian akan dilakukan di Badan Keuangan Kabupaten Kepulauan Siau Tagulandang Biaro (SITARO). Dengan alamat : Jln. Lokongbanua, Kelurahan Ondong Kompleks Kantor Bupati Kecamatan Siau Barat. Waktu penelitian dilaksanakan pada bulan Juni 2017.

\subsection{Metode Pengumpulan Data}

Jenis Data

Data adalah sekumpulan informasi yang diperlukan untuk pengambilan keputusan (Kuncoro, 2011)

Data kualitatif merupakan sebuah kegiatan untuk mengatur, mengurutkan, mengelompokkan, memberi kode atau tanda, dan mengkategorikannya sehingga diperoleh suatu temuan berdasarkan fokus atau masalah yang ingin dijawab (Sujarweni, 2014: 8).

\section{Sumber Data}

Sumber data primer dalam penelitian ini yaitu data hasil wawancara dengan pihak terkait di Badan Keuangan Kabupaten Kepulauan Siau Tagulandang Biaro berupa data Proses Pelaksanaan Pemungutan BPHTB, serta Penerimaan Pajak BPHTB.

Sumber data sekunder dalam penelitian ini diperoleh dari buku-buku, internet, undang-undang, peraturan-peraturan, surat keputusan.

\section{Teknik Pengumpulan Data}

1. Wawancara

2. Observasi

3. Dokumentasi

\section{4. $\quad$ Metode Analisis}

Metode analisis yang digunakan dalam penelitian ini adalah metode analisis deskriptif. Metode analisis ini digunakan untuk mendeskripsikan Mekanisme Pemungutan Pajak atas Pemindahan Hak pada Jual Beli Tanah Dan Bangunan Di Kabupaten Kepulauan Siau Tagulandang Biaro.

\section{HASIL ANALISIS DAN PEMBAHASAN}

\subsection{Hasil Penelitian}

Peraturan Dasar Pengenaan BPHTB Kabupaten Kepulauan Siau Tagulandang Biaro

Aturan dasar pengenaan Bea Perolehan Hak atas Tanah dan Bangunan (BPHTB) yang dilaksanakan di Kabupaten Kepulauan Siau Tagulandang Biaro adalah sebagai berikut :

1. Pemungutan Bea Perolehan Hak atas Tanah dan Bangunan (BPHTB) diatur dalam Peraturan Daerah Kabupaten Kepulauan Siau Tagulandang Biaro Nomor 5 Tahun 2011 tentang Pajak Daerah pada Bagian Kedelapan.

2. Dengan nama Bea Perolehan Hak atas Tanah dan Bangunan (BPHTB) dipungut pajak atas setiap perolehan hak atas tanah dan/atau bangunan dengan tarif 5\% dari NJOP, harga transaksi, nilai pasar. 
3. Subjek pajak dan wajib pajak Bea Perolehan Hak atas Tanah dan Bangunan (BPHTB) adalah orang atau badan yang memperoleh hak atas tanah dan/atau bangunan.

4. Perolehan Hak atas Tanah dan Bangunan sebagai mana dimaksud meliputi:

a. Pemindahan hak karena:

Jual beli, Tukar menukar, Hibah, Hibah wasiat, Waris, Pemasukan dalam perseroan atau badan hukum lain, Pemisahan hak yang mengakibatkan peralihan, Penunjukan pembeli dalam lelang, Pelaksanaan putusan hakim yang mempunyai kekuatan hukum tetap, Penggabungan usaha, Peleburan usaha, Pemekaran usaha, Hadiah.

b. Pemberian hak baru karena:

Kelanjutan pelepasan hak atau Diluar pelepasan hak.

5. Dasar pengenaan Bea Perolehan Hak atas Tanah dan Bangunan (BPHTB) adalah Nilai Perolehan Objek Pajak, jika Nilai Perolehan Objek Pajak tidak diketahui atau lebih rendah dari NJOP PBB pada tahun terjadinya perolehan, dasar pengenaan yang dipakai adalah NJOP Pajak Bumi dan Bangunan.

6. Besarnya Nilai Perolehan Objek Pajak Tidak Kena Pajak ditetapkan sebesar Rp. 60.000.000 (enam puluh juta rupiah) untuk setiap wajib pajak. Dan untuk perolehan hak karena waris atau hibah wasiat NPOPTKP ditetapkan sebesar Rp. 300.000 .000 (tiga ratus juta rupiah).

\section{Mekanisme Pemungutan Pajak BPHTB di Kabupaten Kepulauan Siau Tagulandang Biaro (SITARO)}

\section{Alur Pemungutan BPHTB di Kabupaten Kepulauan Siau Tagulandang Biaro} (SITARO)

Dikembalikan untuk dilengkapi

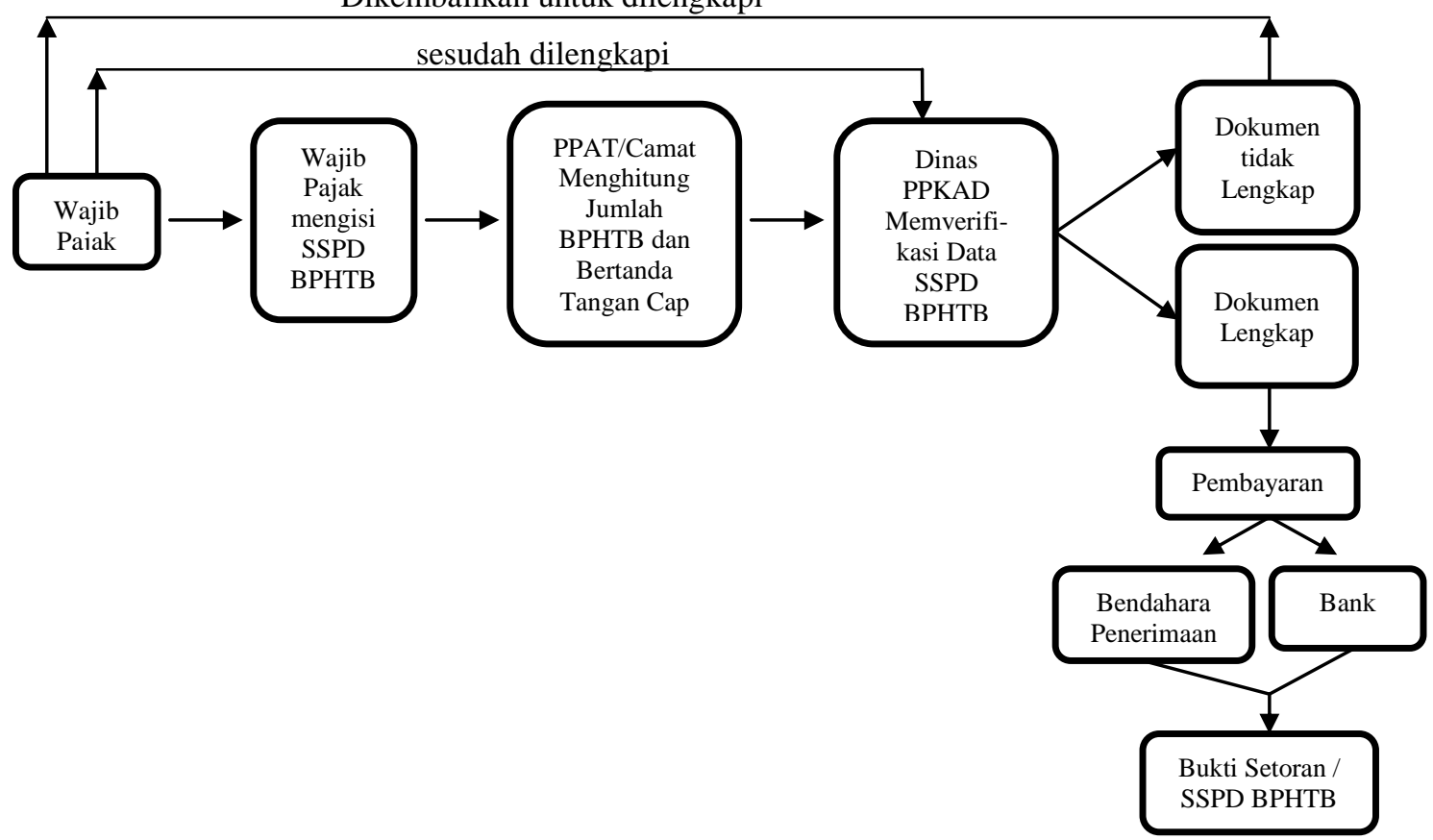

Sumber Data: Badan Keuangan Kab.Kepl Siau Tagulandang Biaro 
Secara Umum Mekanisme Pemungutan BPHTB di Badan Keuangan Kabupaten Kepulauan Siau Tagulandang Biaro sebagai berikut:

1. Wajib Pajak akan menerima SSPD BPHTB (Surat Setoran Pajak Daerah Bea Perolehan Hak atas Tanah dan Bangunan) dan diisi dengan lengkap dan benar. SSPD BPHTB (Surat Setoran Pajak Daerah Bea Perolehan Hak atas Tanah dan Bangunan) merupakan surat yang oleh wajib pajak digunakan untuk melakukan pembayaran atau penyetoran pajak terutang ke Kas Daerah dan sekaligus melaporkan data perolehan hak atas tanah dan/atau bangunan. SSPD (Surat Setoran Pajak Daerah) BPHTB ini terdiri dari 6 lembar, dengan perincian sebagai berikut :

- Lembar 1 untuk Wajib Pajak sebagai bukti pembayaran

- Lembar 2 untuk PPAT/Notaris sebagai arsip

- Lembar 3 untuk Kantor Bidang pertanahan sebagai lampiran permohonan pendaftaran

- Lembar 4 untuk Dinas Pendapatan Pengelolaan Keuangan dan Aset daearah sebagai lampiran permohonan penelitian SSPD BPHTB dan arsip

- Lembar 5 untuk Bank tempat pembayaran

- Lembar 6 untuk Bagian Pengelolaan Keuangan sebagai arsip

2. PPAT/Camat membantu wajib pajak menghitung jumlah BPHTB yang terutang dan mencantumkan di SSPD (Surat Setoran Pajak Daerah) BPHTB dan bertanda tangan cap.

3. Kemudian SSPD (Surat Setoran Pajak Daerah) BPHTB yang sudah diisi dan ditanda tangani cap di bawah ke Dinas Pendapatan untuk dilakukan proses verifikasi data SSPD (Surat Setoran Pajak Daerah) BPHTB.

4. Pada saat verifikasi data SSPD (Surat Setoran Pajak Daerah) BPHTB. Jika dokumen lengkap wajib pajak melakukan pembayaran BPHTB terutang ke Bendahara Penerimaan Dinas/ Bank dan wajib pajak menerima bukti setoran/ SSPD BPHTB. Pada saat verifikasi Jika dokumen tidak lengkap maka SSPD (Surat Setoran Pajak Daerah) BPHTB dikembalikan kepada wajib pajak untuk dilengkapi kembali. Setelah dokumen dilengkapi wajib pajak membawa kembali SSPD (Surat Setoran Pajak Daerah) BPHTB ke dinas untuk dilakukan proses verifikasi. Jika data dinyatakan lengkap selanjutnya wajib pajak melakukan pembayaran BPHTB terutang melalui Bendahara Penerimaan/ Bank.

5. Pada proses pembayaran Wajib Pajak menyerahkan SSPD (Surat Setoran Pajak Daerah) BPHTB yang sudah diverifikasi dan dinyatakan benar kepada Bendahara Penerimaan Dinas Pendapatan Kabupaten Kepulauan SITARO, pada saat bersamaan wajib pajak membayarkan BPHTB terutang melalui Bendahara Penerimaan Dinas Pendapatan Kabupaten Kepulauan SITARO

6. Bendahara Penerimaan Dinas Pendapatan Kabupaten Kepulauan SITARO menerima SSPD (Surat Setoran Pajak Daerah) BPHTB dan uang pembayaran BPHTB terutang dari Wajib Pajak. Bendahara Penerimaan Dinas Pendapatan Kabupaten Kepulauan SITARO kemudian memeriksa kelengkapan pengisian SSPD (Surat Setoran Pajak Daerah) BPHTB dan kesesuaian besaran nilai BPHTB terutang dengan uang pembayaran yang diterima dari Wajib Pajak. 


\section{Penerimaan BPHTB Kabupaten Kepulauan Siau Tagulandang Biaro (SITARO)} Tahun 2012 - 2016

\begin{tabular}{|c|c|c|c|c|}
\hline No & Tahun & Anggaran (Rp) & Realisasi (Rp) & Presentase (\%) \\
\hline $\mathbf{1}$ & 2012 & 60.000 .000 & 79.567 .500 & $132,61 \%$ \\
\hline $\mathbf{2}$ & 2013 & 60.000 .000 & 32.500 .000 & $54,16 \%$ \\
\hline $\mathbf{3}$ & 2014 & 60.000 .000 & 24.302 .800 & $40,50 \%$ \\
\hline $\mathbf{4}$ & 2015 & 60.000 .000 & 73.824 .875 & $123,04 \%$ \\
\hline $\mathbf{5}$ & 2016 & 477.241 .929 & 441.659 .091 & $92,54 \%$ \\
\hline \multicolumn{7}{r}{} \\
\hline
\end{tabular}

Sumber Data: Badan Keuangan Kab. Kepl. Siau Tagulandang Biaro

Total Penerimaan BPHTB yang sudah terealisasi pada tahun 2012-2016 sebesar Rp. 651.854.266 dari yang dianggarkan sebesar Rp. 717.241.929

\subsection{Pembahasan}

Hasil penelitian ini tentang mekanisme pemungutan pajak bea perolehan hak atas tanah dan bangunan di Kabupaten Kepulauan Siau Tagulandang Biaro berjalan sesuai dengan proses, namun ada wajib pajak yang tidak menjalankan proses dengan benar. Hal ini dibuktikan pada proses pengisian (Surat Setoran Pajak Daerah Bea Perolehan Hak atas Tanah dan Bangunan) SSPD BPHTB wajib pajak mengisi data tidak sesuai, kemudian PPAT/camat yang membantu menghitung jumlah BPHTB terutang melampirkan jumlah harga jual tanah dan bangunan yang tidak sesuai dengan bukti transaksi jual beli tanah dan bangunan. Sehingga pada saat data SSPD BPHTB yang akan dibawah ke dinas untuk diverifikasi, data tersebut tidak lengkap atau tidak sesuai.

Pada saat verifikasi/penelitian data dari wajib pajak berupa data SSPD (Surat Setoran Pajak Daerah) BPHTB ditemukan ada harga transaksi yang tidak sesuai dengan bukti transaksi jual beli tanah dan bangunan di kelurahan. Karena wajib pajak tidak mengisi data dengan sebenarnya dan melaporkan Nilai Perolehan Objek Pajak (NPOP) atau harga transaksi yang berbeda. Sehingga pihak verifikasi/peneliti data SSPD (Surat Setoran Pajak Daerah) BPHTB menganggap dokumen tersebut tidak lengkap dan mengembalikan data ke wajib pajak untuk dilengkapi kembali. Hal ini menyebabkan pihak verifikasi bekerja dua kali untuk meneliti kembali SSPD BPHTB wajib pajak yang sudah dilengkapi, sehingga terjadi proses yang sangat panjang dan mengulang-ulang serta membuang waktu dan mengakibatkan hambatan dalam pemungutan pajak.

Proses pembayaran dilakukan ketika dokumen SSPD BPHTB yang diverifikasi lengkap dan dinyatakan benar. Kemudian dilakukan pembayaran melalui bendahara penerima atau melalui bank, ketika wajib pajak menyerahkan SSPD BPHTB dan uang pembayaran BPHTB terutang, wajib pajak menerima bukti setoran/ SSPD BPHTB sebagai bukti pembayaran BPHTB terutang yang sah.

Mekanisme pemungutan bea perolehan hak atas tanah dan bangunan yang dilakukan di Kabupaten Kepulauan Siau Tagulandang Biaro masih belum terlaksana secara efektif, dikarenakan proses pemungutan yang dilakukan untuk mencapai tujuan yaitu meningkatkan penerimaan pajak BPHTB tersebut tidak terlaksana dengan baik dan tepat. Dikatakan efisien apabila proses pemungutan yang dilakukan dilaksanakan sesuai dengan prosesnya sehingga tidak membuang-buang waktu dan mengulang-ulang proses pemungutan sehingga hasil yang didapatkan juga baik dan tepat.

Hasil wawancara dengan kepala bagian bidang pendapatan selaku dinas terkait setiap tahunnya memberikan sosialisasi atau penyampaian kepada perangkat-perangkat desa, untuk 
disampaikan kepada wajib pajak tentang pengenaan Bea Perolehan Hak atas Tanah dan Bangunan (BPHTB). Hal ini membuktikan pemahaman wajib pajak di Kabupaten Kepulauan Siau Tagulandang Biaro yang masih kurang tentang BPHTB. Dan dibuktikan juga dengan hasil wawancara dengan beberapa wajib pajak.

\section{KESIMPULAN DAN SARAN}

\subsection{Kesimpulan} berikut:

Dari hasil penelitian dan pembahasan di atas, maka dapat ditarik kesimpulan sebagai

Mekanisme Pemungutan Bea Perolehan Hak atas Tanah dan Bangunan di Kabupaten Kepulauan SITARO, pelaksanaanya diatur dalam Peraturan Daerah Kabupaten Kepulauan Siau Tagulandang Biaro Nomor 5 Tahun 2011 tentang Pajak Daerah pada Bagian Kedelapan tentang BPHTB. Dalam pelaksanaan pemungutan terdapat beberapa tahapan yang harus dilalui, yaitu Tahap pengisian Surat Setoran Pajak Daerah BPHTB, Tahap Perhitungan Besarnya Bea Perolehan Hak atas Tanah dan Bangunan terutang dan yang harus dibayar, Tahap Verifikasi, dan Tahap Pembayaran. Mekanisme pemungutan ini berjalan sesuai dengan prosesnya, namun sedikit tambahan ada pihak yang tidak melaksanakan proses pemungutan BPHTB sebagaimana mestinya.

\subsection{Saran}

Bidang Pendapatan selaku instansi yang melaksanakan pemungutan pajak Bea Perolehan Hak atas Tanah dan Bangunan. Sebaiknya lebih memperhatikan lagi proses pemungutan pajak atas pemindahan hak ada jual beli tanah dan bangunan agar lebih mudah dipahami oleh wajib pajak, dan tidak berbelit-belit prosesnya. Sehingga dikemudian hari pelaksanaan pemungutan bisa terlaksana dengan baik dan sesuai prosesnya agar mendapatkan hasil dari pemungutan yang diinginkan guna meningkatkan penerimaan pajak BPHTB.

\section{DAFTAR PUSTAKA}

Anggraini, Elga, 2015. “Analisis Penerapan Pemungutan Bea Perolehan Hak atas Tanah dan Bangunan (BPHTB) Di Kabupaten Malang". Jurnal Administrasi BisnisPerpajakan (JAB). Vol. 6 No. 1 2015. Universitas Brawijaya. Diakses pada 5 Juni 2017.

Arianti, Merda, 2014." Mekanisme Pemungutan Pajak Bea Perolehan Hak atas Tanah dan Bangunan (BPHTB) Pada Kantor Dinas Pengelolaan Keuangan dan Aset Kabupaten Rokan Hulu". Universitas Islam Negeri Sultan Syarif Kasim. Diakses pada 11 Mei 2017.

Cahyono, Andi, 2014. "Analisa Pemungutan Bea Perolehan Hak atas Tanah dan Bangunan (BPHTB) Dalam Hal Jual Beli Tanah dan Bangunan Di Kota Blitar ”. Journal Stieken. Diakses pada 4 Juni 2017.

Hidayat, Muchtar. 2011. Pengantar Perpajakan. Jember. Center for Society Studies.

Kuncoro, Mudrajad, 2011. Metode Riset untuk Bisnis dan Ekonomi, Penerbit Erlangga, Jakarta.

Kuncoro, Mudrajad, 2013. Metode Riset untuk Bisnis dan Ekonomi. Edisi 4. Penerbit Erlangga. Jakarta.

Mardiasmo, 2016. Perpajakan, Edisi Revisi, Penerbit Andi, Yogyakarta.

Peraturan Daerah Kabupaten Kepulauan Siau Tagulandang Biaro Nomor 5 Tahun 2011 Tentang Pajak Daerah.

Resmi, Siti, 2012. Perpajakan Teori dan Kasus Edisi 6 buku 2, Salemba Empat, Jakarta. 
Rooy, 2016. “Analisis Kontribusi Penerimaan Pajak Daerah Terhadap Pendapatan Asli Daerah (PAD)Di Kabupaten Raja Ampat". Jurnal EMBA. Vol.3 No.4. ISSN 23031174.

Soewardi, Tiara, 2014."Dinamika Pengelolaan BPHTB Setelah Dialihkan Menjadi Pajak Daerah” Jurnal Universitas Brawijaya Malang. Diakses pada 8 Mei 2017.

Sujarweni, Wiratna. 2014. Metodologi Penelitian Lengkap, Praktis dan Mudah Dipahami, Pustaka Baru Pers. Yogyakarta.

Supriyanto, Edy. 2011. Akuntansi Perpajakan. Yogyakarta: Graha Ilmu.

Undang-Undang Nomor 16 Tahun 2009 tentang Ketentuan Umum dan Tata Cara Perpajakan.Jakarta.

Undang-Undang Nomor 28 Tahun 2009 tentang Pajak Daerah dan Retribusi Daerah.Jakarta.

Windy, 2016. "Analisis Dasar Pengenaan dan Kontribusi Bea Perolehan Hak atas Tanah dan Bangunan Terhadap Pendapata Asli Daerah Kota Ternate”. Jurnal EMBA. Vol. 3, No. 4. (2015). 